\title{
Analisis Kemampuan Berpikir Kritis Mahasiswa Program Studi Hukum Keluarga Islam IAIN Syaikh Abdurrahman Siddik Bangka Belitung
}

\author{
Rahmat Danni $^{1}$, Tauratiya ${ }^{2}$ \\ ${ }^{1}$ IAIN Syaikh Abdurrahman Siddik, Indonesia, \\ ${ }^{2}$ IAIN Syaikh Abdurrahman Siddik, Indonesia
}

\author{
Info Artikel : \\ Diterima 9 April 2020 \\ Direvisi 21 April 2020 \\ Dipublikasikan 27 April 2020
}

\section{Kata Kunci:}

Kemampuan Berpikir Kritis

Hukum Keluarga Islam

Rasch Model

\author{
Keywords: \\ Critical Thinking Ability \\ Islamic Family Law \\ Rasch Model
}

\begin{abstract}
ABSTRAK
Penelitian ini bertujuan untuk mendekripsikan kemampuan berpikir kritis mahasiswa Program Studi Hukum Keluarga Islam IAIN Syaikh Abdurrahman Siddik Bangka Belitung pada mata kuliah Ilmu Hukum. Penelitian ini merupakan penelitian deskripif dengan pendekatan kuantitatif. Populasi penelitian ini adalah mahasiswa Program Studi Hukum Keluarga Islam. Penentuan sampel menggunakan teknik sampling jenuh dengan jumlah 91 mahasiswa. Pengumpulan data menggunakan teknik tes yang terdiri dari 15 butir soal pilihan ganda. Validitas instrumen dibuktikan menggunakan penilaian ahli yang dianalisis berdasarkan rumus $V$ Aiken. Instrumen terbukti valid dengan indeks 0,76 . Reliabilitas instrumen diestimasi menggunakan rumus cronbach alpha dan didapati koefisien reliabilitas sebesar 0,74. Hasil estimasi kemampuan berpikir kritis mahasiswa menggunakan pendekatan Rasch model diketahui sebanyak 32\% mahasiswa memiliki kemampuan tergolong tinggi, $2 \%$ mahasiswa tergolong rendah, dan $66 \%$ mahasiswa memiliki kemampuan tergolong sedang. Rata-rata kemampuan berpikir kritis mahasiswa Program Studi HKI tergolong sedang dengan nilai logit sebesar $+1,1$ atau 63,8 dalam skala 0 s.d. 100
\end{abstract}

\begin{abstract}
This study aims to describe the critical thinking skills of students of the Islamic Family Law Study Program IAIN Sheikh Abdurrahman Siddik Bangka Belitung in the Law Science course. This research is a descriptive study with a quantitative approach. The population of this study are students of the Islamic Family Law Study Program. Determination of the sample using a saturated sampling technique with a total of 91 students. Data collection uses a test technique consisting of 15 multiple choice questions. The validity of the instrument was proven using expert judgment which was analyzed based on the Aiken V formula. The instrument proved to be valid with an index of 0.76. Instrument reliability was estimated using the Cronbach alph a formula and a reliability coefficient of 0.74 was found. The estimated results of students' critical thinking skills using the Rasch model approach show that 32\% of students have high ability, 2\% of students are low, and $66 \%$ of students have moderate ability. The average critical thinking ability of IPR Study Program students is moderate with a logit value of +1.1 or 63.8 on a scale of 0 to. 100
\end{abstract}

Koresponden:

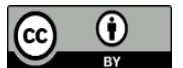

This is an open access article distributed under the Creative Commons Attribution License, which permits unrestricted use, distribution, and reproduction in any medium, provided the original work is properly cited. (O2019 by author.

Rahmat Danni

Email: rahmatdanni@iainsasbabel.ac.id.

\section{Pendahuluan}

Revolusi industri 4.0 menuntut setiap sektor untuk berbenah. Salah satu sektor yang merasakan dampak paling besar dari revolusi industri 4.0 adalah sektor pendidikan. Pendidikan diharapkan untuk membentuk sumber daya manusia yang berkualitas dan berkemampuan sesuai yang dibutuhkan oleh user atau pengguna lulusan. Wagner (2008) mengungkapkan sejumlah kemampuan yang dibutuhkan pada abad 21, yaitu kemampuan berpikir kritis dan memecahkan masalah, mampu berkolaborasi dan memimpin, cakap dan mudah beradaptasi, inisiatif dan berjiwa entrepreneur, terampil dalam berkomunikasi baik lisan maupun tulisan, terampil menelusuri dan menganalisa informasi, memiliki rasa ingin tahu dan imajinasi tinggi. Hal ini diperkuat oleh Trilling \& Fadel (2009) yang menegaskan bahwa seorang lulusan harus memiliki kemampuan komunikasi yang baik, berpikir kritis dan pemecahan masalah, profesional dan menjunjung 
etika, mampu kerja tim, mengaplikasikan teknologi, dan berjiwa pemimpin. Oleh karena itu, demi melahirkan lulusan yang berkualitas dan memiliki kemampuan sesuai kebutuhan maka diperlukan pendidikan yang berkualitas dan ditopang dengan kurikulum yang relevan dengan perkembangan zaman.

Kemampuan berpikir kritis menjadi salah satu kemampuan yang dibutuhkan di abad 21. Berpikir kritis didefinisikan sebagai sebuah bentuk proses kognitif kompleks yang diintegrasikan oleh beberapa kemampuan yang saling terkait sehingga memungkinkan untuk mengevaluasi, memproses secara analitis dan refleksif, menerima atau menolak suatu informasi (Tung \& Chang, 2009). Sedangkan Moore \& Stanley (2010) mendefinisikan berpikir kritis sebagai suatu kegiatan kognitif yang mengkombinasikan kelogisan berpikir baik deduktif maupun induktif. Disamping itu, Nitko \& Brookhart (2011, p. 237) mengemukakan aspek pada berpikir kritis yaitu elementary clarification, basic support, inference, advance clarification, and strategy and tactics. Dengan demikian, berpikir kritis didefinisikan sebagai suatu kemampuan kognitif kompleks yang memungkinkan seseorang mampu mengevaluasi, menganalisa, menerima dan menolak suatu informasi melalui kelogisan berpikir.

Berpikir kritis dianggap relevan dalam pembelajaran di perguruan tinggi (Hernández \& Grijalva, 2020). Akan tetapi, pengembangan keterampilan berpikir kritis masih minim dalam pendidikan (Santrock, 2012). Hal tersebut terjadi karena sebagian pendidik masih cenderung menitikberatkan pembelajaran pada kegiatan mengingat (recall), mengemukakan kembali (restate), dan mengutip tanpa pengolahan (recite). Pembelajaran konvensional berdampak pada kemampuan berpikir kritis mahasiswa menjadi tumpul karena tidak terlatih secara maksimal. Selain itu, keadaan akan menjadi lebih sulit ketika budaya literasi mahasiswa masih rendah.

Sebagai upaya mempersiapkan lulusan yang berkualitas dan memiliki kemampuan sesuai kebutuhan pengguna lulusan maka perlu dilakukan pengukuran mengenai kemampuan berpikir mahasiswa. Pengukuran dilakukan pada mahasiswa Program Studi Hukum Keluarga Islam (HKI) di Institut Agama Islam Negeri (IAIN) Syaikh Abdurrahman Siddik Bangka Belitung pada mata kuliah Ilmu Hukum. Demi menghasilkan data yang lebih objektif dan akurat maka pengukuran kemampuan berpikir kritis mahasiswa HKI dilakukan menggunakan Rasch model. Rasch model merupakan bagian dari teori respon butir yaitu suatu teori pengukuran yang berkembang guna mengatasi kelemahan dari teori tes klasik (Mardapi, 2012; Sarea \& Ruslan, 2019). Teori tes klasik merupakan teori pengukuran konvensional yang telah lama digunakan, akan tetapi terdapat kelemahan dari teori ini yaitu hasil pengukuran bergantung pada karakteristik soal yang diujikan dan parameter item soal bergantung pada kemampuan peserta tes (Azwar, 2012; Hambleton, R. K. Swaminathan \& Rogers, 1991; Hambleton \& Swaminathan, 1985). Artinya, kemampuan peserta tes akan tinggi apabila diujikan dengan soal yang memiliki tingkat kesukaran rendah dan akan rendah apabila diujikan dengan soal yang yang memiliki tingkat kesukaran tinggi.

Memperbaiki kelemahan teori tes klasik, Rasch model hadir dengan tiga asumsi mendasar yaitu unidimensi, independensi lokal, dan invariansi parameter (DeMars, 2018; Hambleton, R. K. Swaminathan \& Rogers, 1991; Naga, 1992). Unidimensi yaitu butir soal hanya mengukur satu kompetensi (Sarea \& Ruslan, 2019). Independensi yaitu peluang peserta tes dalam menjawab setiap butir soal dengan benar bersifat independen (van der Linden \& Hambleton, 2013). Invariansi parameter yaitu karakteristik butir soal akan konsiten meski diujikan pada kemampuan peserta tes yang berbeda (Schulz \& Fraillon, 2011). Berdasarkan asumsi dasar tersebut dapat disimpulkan bahwa pengukuran menggunakan Rasch model memberikan informasi kemampuan peserta tes yang sebenarnya. Peserta tes berkemampuan tinggi akan berpeluang besar menjawab benar butir soal yang memiliki tingkat kesukaran tinggi, sedangkan peserta berkemampuan rendah berpeluang kecil menjawab benar butir soal yang memiliki tingkat kesukaran tinggi. Dengan begitu, kesuksesan peserta tes dalam menyelesaikan soal bergantung pada kemampuan dirinya sendiri.

\section{Metode}

Penelitian ini merupakan penelitian deskriptif dengan pendekatan kuantitatif. Subjek penelitian adalah seluruh mahasiswa Program Studi Hukum Keluarga Islam Fakultas Syariah dan Ekonomi Islam IAIN Syaikh Abdurrahman Siddik Bangka Belitung yang berjumlah 91 orang. Teknik sampling yang digunakan adalah teknik sampel jenuh sehingga memungkinkan semua subjek terpilih menjadi sampel. Penelitian dilakukan pada bulan Januari 2020. Pengumpulan data dilakukan menggunakan teknik tes berbentuk pilihan ganda yang berjumlah 15 butir soal dengan 5 alternatif jawaban. Butir soal dikonstruk berdasarkan tiga indikator yaitu mengevaluasi, menganalisa, dan menyimpulkan/menafsirkan informasi berkaitan dengan materi Ilmu Hukum yaitu mengenai Kaidah sosial dan hukum, Penegakkan dan penemuan hukum, 
dan Kesadaran hukum. Validitas instrumen berupa validitas isi (content validity) yang dibuktikan melalui penilaian pakar (expert judgement). Pakar berjumlah 3 orang yang terdiri dari 2 orang pakar dibidang Ilmu Hukum dan 1 orang dibidang Evaluasi Pendidikan. Hasil penilaian ahli diolah melalui formula $V$ Aiken (Aiken, 1980). Pengestimasian reliabilitas instrument dilakukan menggunakan formula Cronbach's Alpha (Cronbach, 1951) melalui aplikasi SPSS v.22.

Pengukuran kemampuan berpikir kritis $(\theta)$ dilakukan menggunakan pendekatan Rasch Model melalui aplikasi Winstep. Pada pendekatan Rasch Model kemampuan dikuantifikasikan dalam bentuk logit yang memiliki rentang -4 s.d. +4 (Sumintono \& Widhiarso, 2015). Guna memudahkan dalam memahami kemampuan berpikir kritis mahasiswa maka logit dikonversi ke dalam skala 0 s.d. 100 melalui rumus Ability $=\left(12,5^{*}\right.$ Theta $)+50$ (Kartianom \& Retnawati, 2018). Selanjutnya kemampuan dikelompokkan menjadi 3 kategori yaitu tinggi $(M+1 S D \leq X)$, sedang $(M-1 S D \leq M+1 S D)$, dan rendah $(X<M-1 S D)(A z w a r$, 2012). Pengkategorian kemampuan didasari asumsi bahwa kemampuan berpikir kritis mahasiswa terdistibusi secara normal.

\section{Hasil dan Pembahasan}

Hasil penilaian ahli terhadap instrumen pengukur kemampuan berpikir kritis mahasiswa pada mata kuliah Ilmu Hukum diperoleh indeks $V$ Aiken sebesar 0,76. Berdasarkan hasil tersebut dapat disimpulkan bahwa validitas instrumen kemampuan berpikir kritis mahasiswa Program Studi Hukum Keluarga Islam tergolong cukup. Sebagaimana yang kemukakan oleh Retnawati (2016) bahwa indeks di rentang 0,4-0,8 dikatakan validitas cukup (mediocare). Selanjutnya pengestimasian reliabilitas menggunakan formula cronbach's alpha diperoleh koefisien sebesar 0,74, sehingga dapat diinterpretasikan bahwa instrumen kemampuan berpikir kritis memiliki reliabilitas yang cukup. Hal ini ditegaskan oleh Fisher (2007) dan Azwar (2015) bahwa koefisien reliabilitas direntang 0,67 - 0,8 masuk ke dalam kategori cukup.

Selain dapat mengukur kemampuan $(\theta)$ secara objektif, pendekatan Rasch Model dapat pula mengetahui karakteristik butir soal diantaranya mengenai kecocokan butir soal terhadap model (item fit) dan tingkat kesukaran butir soal. Kecocokan butir soal terhadap model merupakan gambaran sejauh mana butir soal berfungsi melakukan pengukuran (Sumintono \& Widhiarso, 2015). Senada dengan itu Alfarisa \& Purnama (2019) mengungkapkan bahwa item fit membuktikan butir berperilaku konsisten sesuai yang diharapkan model. Apabila didapati butir soal tidak fit, maka kemungkinan peserta uji (testee) mengalami miskonsepsi dalam mengerjakan butir soal. Kecocokan butir soal terhadap model dapat diketahui melalui nilai outfit means-square $(0,5<\mathrm{MNSQ}<1,5)$, outfit $z$-standard $(-2,0<\mathrm{ZSTD}<+2,0)$, dan point measure correlation $(0,4<$ Pt Measure Corr < 0,85) (Bond \& Fox, 2015; Boone, Staver, \& Yale, 2014). Hasil analisis item fit diketahui bahwa dari 15 butir soal terdapat 1 butir (7\%) yang tidak memenuhi kriteria outfit $z$-standard yaitu butir soal no 7 dengan nilai Outfit ZSTD sebesar 3,0. Sumintono \& Widhiarso (2015) menjelaskan bahwa nilai ZTSD dipengaruhi oleh jumlah sampel, semakin besar sampel nilai ZTSD cenderung di atas 3,0, kemudian apabila terdapat butir soal yang tidak memenuhi satu dari tiga kriteria yang telah ditentukan maka butir soal tetap dipertahankan.

Tingkat kesukaran (b) butir soal pengukur kemampuan berpikir kritis mahasiswa Program Studi Hukum Keluarga Islam dapat diketahui melalui item measure. Tingkat kesukaran butir soal yang baik berada pada rentang -2 s.d. +2 (DeMars, 2018; Hambleton \& Swaminathan, 1985; Mardapi, 1998; Retnawati, 2014; Sumintono \& Widhiarso, 2015). Apabila indeks kesukaran suatu butir soal mendekati +2 maka tingkat kesukaran butir cenderung sulit, sebaliknya apabila mendekati -2 maka butir soal cenderung memiliki tingkat kesukaran yang relatif mudah, sedangkan butir dengan indeks kesukaran direntang $-1,0<\mathrm{b}<+1,0$ dikategorikan sedang (Susetyo, 2015). Hasil analisis tingkat kesukaran butir soal menggunakan pendekatan Rasch model dengan aplikasi Winstep ditampilkan pada Tabel 1.

Tabel 1. Tingkat kesukaran butri soal

\begin{tabular}{ccccccccc}
\hline Butir & $\begin{array}{c}\text { Tingkat } \\
\text { Kesukaran }\end{array}$ & Kategori & Butir & $\begin{array}{c}\text { Tingkat } \\
\text { Kesukaran }\end{array}$ & Kategori & Butir & $\begin{array}{c}\text { Tingkat } \\
\text { Kesukaran }\end{array}$ & Kategori \\
\hline 1 & 0,03 & Sedang & 6 & 1,20 & Sulit & 11 & $-0,11$ & Sedang \\
2 & $-0,11$ & Mudah & 7 & $-0,33$ & Sedang & 12 & $-1,92$ & Mudah \\
3 & $-2,10$ & SM $^{*}$ & 8 & 0,84 & Sedang & 13 & 0,54 & Sedang
\end{tabular}




\begin{tabular}{llccccccc}
4 & $-2,10$ & SM $^{*}$ & 9 & 2,20 & SS $^{*}$ & 14 & 0,72 & Sedang \\
5 & $-0,66$ & Sedang & 10 & 1,08 & Sulit & 15 & 0,72 & Sedang \\
\hline *SM : Sangat Mudah \\
* SS : Sangat Sulit
\end{tabular}

Tabel 1 menunjukkan dari 15 butir soal kemampuan berpikir kritis pada mata kuliah Ilmu Hukum terdapat 2 butir (13\%) berkategori sangat mudah, 2 butir (13\%) berkategori mudah, 8 butir (54\%) berkategori sedang, 2 butir (13\%) berkategori sulit, dan 1 butir soal (7\%) berkategori sangat sulit. Butir no 9 sebagai butir sangat sulit hanya mampu dijawab dengan benar oleh 28 mahasiswa dari 91 mahasiswa secara keseluruhan. Sedangkan butir no 3 dan 4 tergolong sebagai butir sangat mudah mampu dijawab dengan benar oleh 84 mahasiswa dari 91 mahasiswa secara keseluruhan. Selain tingkat kesukaran butir soal, pendekatan Rasch Model juga dapat menjelaskan mengenai keberfungsian soal/instrument dalam mengukur kemampuan berpikir kritis mahasiswa pada mata kuliah Ilmu Hukum, yaitu melalui diagram plot Test information function yang disajikan pada Diagram 1.

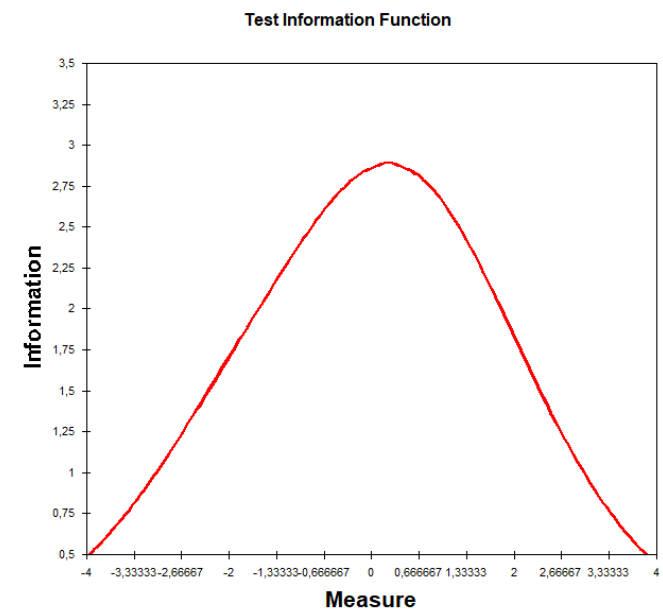

Diagram 1. Test information function

Diagram 1 menginformasikan bahwa instrumen pengukur kemampuan berpikir kritis mahasiswa Program Studi HKI pada mata kuliah Ilmu Hukum yang berjumlah 15 butir cocok digunakan untuk mengukur kemampuan berpikir kritis mahasiswa. Instrumen akan berfungsi secara maksimal apabila digunakan pada mahasiswa berkemampuan sedang dengan nilai logit 0,22 .

Kemampuan berpikir kritis $(\theta)$ mahasiswa Program Studi HKI IAIN Syaikh Abdurrahman Siddik Bangka Belitung diketahui melalui pearson measure pada hasil analisis menggunakan aplikasi Winstep. Kemampuan berpikir kritis $(\theta)$ masih berupa nilai logit dengan rentang nilai -4 s.d. +4 . Hasil tersebut menunjukkan bahwa terdapat 3 orang mahasiswa yang memperoleh nilai +4 sebagai nilai tertinggi dan terdapat 1 orang mahasiswa nilai logit $-3,28$ sebagai nilai terendah. Selanjutnya, guna mempermudah dalam memahami kemampuan berpikir kritis $(\theta)$ mahasiswa Program Studi HKI maka nilai logit dikonversi menjadi skala 0 s.d. 100. Adapun pesebaran kemampuan berpikir kritis $(\theta)$ mahasiswa Program Studi HKI disajikan pada Tabel 2.

Tabel 2. Kamampuan berpikir kritis mahasiswa Program Studi HKI

\begin{tabular}{ccc}
\hline Interval Nilai & Jumlah Mahasiswa & Kategori \\
\hline $\mathrm{X} \geq 66,67$ & 29 & Tinggi \\
$33,33 \leq X<66,67$ & 60 & Sedang \\
$\mathrm{X}<33,33$ & 2 & Rendah \\
\hline
\end{tabular}

Tabel 2. menunjukkan bahwa 32\% mahasiswa Program Studi HKI memiliki kemampuan berpikir kritis $(\theta)$ tergolong tinggi pada mata kuliah Ilmu Hukum, 2\% mahasiswa tergolong rendah, dan 66\% mahasiswa memiliki kemampuan berpikir kritis tergolong sedang/cukup. Hal ini menunjukkan bahwa kemampuan berpikir kritis mahasiswa didominasi oleh mahasiswa berkemampuan sedang. Hasil analisis juga menunjukkan nilai rata-rata mahasiswa adalah $+1,1$ dalam logit atau 63,8 dalam skala 0 s.d. 100 . 
Berdasarkan nilai rata-rata tersebut dapat disimpulkan bahwa kemampuan berpikir kritis mahasiswa Program Studi HKI IAIN Syaikh Abdurrahman Siddik Bangka Belitung pada mata kuliah Ilmu Hukum tergolong sedang. Distribusi kemampuan berpikir kritis mahasiswa Program Studi HKI dan karakteristik butir soal secara gamblang dapat dilihat pada Wright Maps sebagaimana ditampilkan pada Gambar 1.

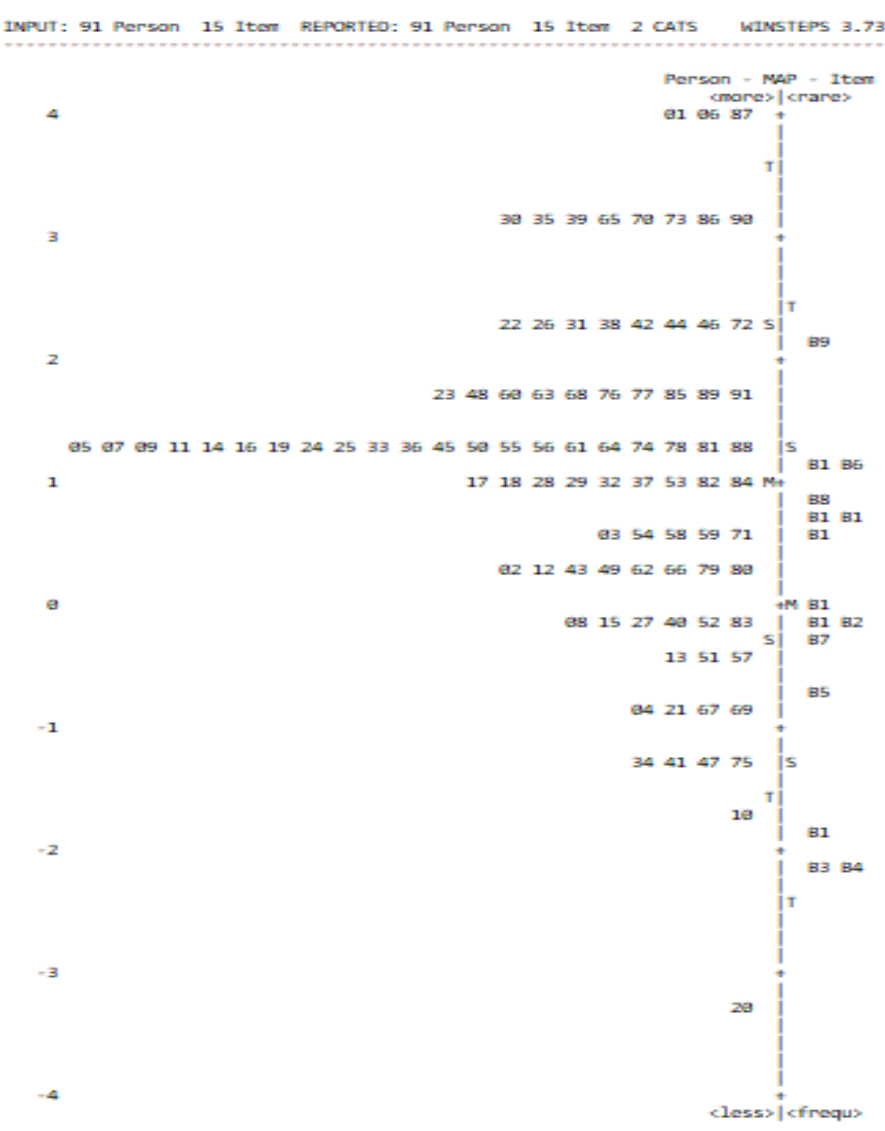

Gambar 1. Wright Maps butir soal dan kemampuan berpikir kritis mahasiswa Program Studi HKI

Berdasarkan Gambar 1 dapat diketahui bahwa mahasiswa no urut 20 memiliki kemampuan terendah dan mahasiswa no urut 01, 06, dan 87 memiliki nilai tertinggi. Sedangkan pada sebaran butir soal dapat diketahui bahwa butir soal no 9 merupakan butir soal paling sulit dikerjakan oleh mahasiswa dan butir no 3 dan 4 menjadi butir soal paling mudah bagi mahasiswa. Selain itu, huruf $\mathrm{M}$ pada daerah pearson menunjukkan rata-rata nilai logit kemampuan berpikir mahasiswa yaitu sebesar 1,1, sedangkan huruf $\mathrm{M}$ pada daerah item menjukkan rata-rata nilai logit tingkat kesukaran butir soal yaitu 0 .

\section{Kesimpulan}

Kemampuan berpikir kritis mahasiswa Program Studi Hukum Keluarga Islam IAIN Syaikh Abdurrahman Siddik tergolong sedang dengan rata-rata nilai logit sebesar $+1,1$ atau 63,8 dalam skala 0 s.d. 100. Hasil ini dapat menjadi bahan evaluasi bagi segenap civitas akademika IAIN Syaikh Abdurrahman Siddik khususnya Program Studi Hukum Keluarga Islam. Upaya meningkatkan kemampuan berpikir kritis mahasiswa sesuai dengan bidang keahlian perlu dilakukan. Salah satunya adalah dengan menerapkan model pembelajaran berbasis higher order thinking skills dalam perkuliahan dengan begitu mahasiswa akan terlatih berpikir kritis dan siap menghadapai era Revolusi Industri 4.0.

\section{Referensi}

Aiken, L. R. (1980). Content Validity and Reliability Of Single Items or Questionnaires. Educational and Psychological Measurement, 40(955-959).

Alfarisa, F., \& Purnama, D. N. (2019). Analisis Butir Soal Ulangan Akhir Semester Mata Pelajaran Ekonomi SMA Menggunakan RASCH Model. Jurnal Pendidikan Ekonomi Undiksha, 11(2), 366-374. https://doi.org/10.23887/JJPE.V11I2.20878 
Azwar, S. (2012). Penyusunan Skala Psikologi (2nd ed.). Yogyakarta: Pustaka Pelajar.

Azwar, S. (2015). Reliabilitas dan Validitas (4th ed.). Yogyakarta: Pustaka Pelajar.

Bond, T., \& Fox, C. (2015). Applying the Rasch Model Fundamental measurement in the Human Sciences (3rd ed.). New York: Routledge.

Boone, W., Staver, J., \& Yale, M. (2014). Rasch Analysis in the Human Sciences. https://doi.org/10.1007/978-94-007-6857-4

Cronbach, L. J. (1951). Coefficient alpha and the internal structure of tests. Psychometrika, (16), $297-334$.

DeMars, C. E. (2018). Classical Test Theory and Item Response Theory. In The Wiley Handbook of Psychometric Testing (pp. 49-73). https://doi.org/10.1002/9781118489772.ch2

Fisher, W. (2007). Rating scale instrument quality criteria. Rasch Measurement Transactions, 21(1), 1095.

Hambleton, R. K. Swaminathan, H., \& Rogers, H. J. (1991). Fundamentals of Item Response Theory. CA: Sage Publication Inc.

Hambleton, R. K., \& Swaminathan, H. (1985). Item Response Theory: Principles and Application. Boston: Kluwer Inc.

Hernández, C. C., \& Grijalva, M. C. P. M. (2020). Critical Thinking In The Practice of Educational Intervention. PARIPEX - Indian Journal of Research, 9(2), 129-130. https://doi.org/10.36106/paripex

Kartianom, \& Retnawati, H. (2018). Why Are Their Mathematical Learning Achievements Different? ReAnalysis Timss 2015 Data In Indonesia, Japan And Turkey. In International Journal on New Trends in Education and Their Implications April. Retrieved from www.ijonte.org

Mardapi, D. (1998). Analisis Butir dengan Teori Tes Klasik dan Teori Respons Butir. Jurnal Kependidikan, $28,25-34$

Mardapi, D. (2012). Pengukuran penilaian dan evaluasi pendidikan. Yogyakarta: Nuha Medika.

Moore, B., \& Stanley, T. (2010). Critical Thinking and Formative Assessment Increasing The Rigor in Your Classroom. New York: Eye On Educatioan, Inc.

Naga, D. S. (1992). Pengantar teori sekor pada pengukuran pendidikan. Jakarta: Gunadarma.

Nitko, A. J., \& Brookhart. (2011). Educational Assessment of Student. Boston: Pearson.

Retnawati, H. (2014). Teori Respons Butir dan Penerapannya. Yogyakarta: Nuha Medika.

Retnawati, H. (2016). Validitas, reliabilitas dan karakteristik butir. Yogyakarta: Nuha Medika.

Santrock, J. W. (2012). Life-span Development (13th ed.). Dallas: Mc Graw-Hill.

Sarea, M. S., \& Ruslan, R. (2019). Karakteristik Butir Soal: Classical Test Theory Vs Item Response Theory? DIDAKTIKA : Jurnal Kependidikan, 13(1), 1-16. https://doi.org/10.30863/didaktika.v13i1.296

Schulz, W., \& Fraillon, J. (2011). (2011). The analysis of measurement equivalence in international studies using the Rasch model. Educational Research and Evaluation, 17(6), 447-464.

Sumintono, B., \& Widhiarso, W. (2015). Aplikasi Pemodelan Rasch pada Assessment Pendidikan. Bandung: Trim Komunikata.

Susetyo, B. (2015). Prosedur Penyusunan dan Analasis Tes. Bandung: PT Refika Aditama.

Trilling, B., \& Fadel, C. (2009). 21st Century skills. San Fransisco: John Wiley \& Sons, Inc.

Tung, C.-A., \& Chang, S.-Y. (2009). Developing Critical Thinking through Literature Reading. In Feng Chia Journal of Humanities and Social Sciences.

van der Linden, W. J., \& Hambleton, R. K. (2013). Handbook of modern item response theory. New York: Springer Science \& Business Media.

Wagner, T. (2008). The Global Achievement GAP. New York: Basic Books. 